\title{
Dondurulmuş Çözülmüş Embriyo Transferi Öncesi Günü Progesteron Seviyesinin İn-Vitro Fertilizasyon Başarısına Etkisinin İncelenmesi
}

\section{Investigation of the Effect of Progesterone Level on In-Vitro Fertilization Success The Day Before Frozen-Thawed Embryo Transfer}

\author{
${ }^{1}$ Özcan BUDAK, ${ }^{2}$ Songül DOĞANAY, ${ }^{3}$ Nermin AKDEMİ,,${ }^{3}$ Mehmet Sühha BOSTANCI, \\ ${ }^{3}$ Arif Serhan CEVRIOĞLU, ${ }^{4}$ Veysel TOPRAK, ${ }^{1}$ Seda ÖZKÜLER \\ ${ }^{1}$ Sakarya Üniversitesi Tıp Fakültesi Histoloji-Embriyoloji Anabilim Dalı, Sakarya, Türkiye \\ ${ }^{2}$ Sakarya Üniversitesi Tıp Fakültesi Fizyoloji Anabilim Dalı, Sakarya, Türkiye \\ ${ }^{3}$ Sakarya Üniversitesi Tıp Fakültesi Kadın Hastalıkları ve Doğum Anabilim Dalı, Sakarya, Türkiye \\ ${ }^{4}$ Özel Tatvan Can Hastanesi Kadın Hastalıkları ve Doğum, Bitlis, Türkiye
}

Özcan Budak: https://orcid.org/ 0000-0002-2617-3175

Songül Doğanay: https://orcid.org/ 0000-0002-1730-1331

Nermin Akdemir: https://orcid.org/ 0000-0002-9129-2103

Mehmet Sühha Bostanc1: https://orcid.org/ 0000-0002-4776-6244

Arif Serhan Cevrioğlu: https://orcid.org/ 0000-0002-3810-6519

Veysel Toprak: https://orcid.org/0000-0002-3280-851X

Seda Özküler: https://orcid.org/0000-0001-5585-0289

\begin{abstract}
ÖZ
Amaç: Dondurulmuş çözülmüş embriyo transfer (DÇET) sikluslarında transfer öncesi gün ölçülen serum progesteron konsantrasyonlarının gebelik, düşük ve canlı doğum oranları üzerine etkilerini gözlemlemek.

Materyal ve Metot: $\mathrm{Bu}$ retrospektif çalışmada, tek bir merkezde 01.01.2019 ile 01.09.2019 tarihleri arasında gerçekleştirilen 67 DÇET siklus sonuçları incelendi. Progesteron düzeyleri 10,64 ng/ml eşik değerinin altındaki ve üstündeki DÇET sikluslarındaki gebelik, düşük ve canl doğum sonuçları karşılaştırıldı.

Bulgular: Progesteron konsantrasyonlarına göre DCET gruplarındaki hastaların yaşı, infertilite nedenleri, sitimülasyon gün sayıları, beden kitle indeks (BKİ) değerleri, endometriyum kalınlıkları ve transfer edilen ortalama embriyo sayıları benzerdi. Gebelik oranları karşılastırıld1ğında progesteronun $>10,65 \mathrm{ng} / \mathrm{ml}$ grubunda gebelik oranları anlamlı derecede yüksekti $(\mathrm{p}=0,023)$. Toplam gebeliklerin \%50 (21)'sinin canlı doğum ile sonuçlandığı, canlı doğumla sonuçlanan gebeliklerin \%90,5 (19)'nin progesteron düzeylerinin $>10,64 \mathrm{ng} / \mathrm{ml}$ olan gebelerden oluştuğu bulundu. Progesteron düzeyleri $<10,64 \mathrm{ng} / \mathrm{ml}$ olanların pozitif gebelerin \%28,6 (12)'sını oluşturduğu, bu gebeliklerin \%83,3 (10)'ünün düşük ile, \%16,7 (2)'sinin de canlı doğum ile sonuçlandığı bulundu.

Sonuç: Progesteron düzeylerinin $>10,64 \mathrm{ng} / \mathrm{ml}$ olduğu sikluslarda gebelik sonuçlarının daha yüksek olduğu ve oluşan gebeliklerin büyük çoğunluğunun canlı doğumla sonuçlandığı görülmektedir.
\end{abstract}

Anahtar Kelimeler: Embriyo transferi, gebelik sonuçları, hormon replasman tedavisi

\section{ABSTRACT}

Objective: To observe the effects of serum progesterone concentrations measured on the day before transfer on pregnancy, miscarriage and live birth rates in frozenthawed embryo transfer (DCE) cycles.

Materials and Methods: In this retrospective study, the results of 67 ICET cycles performed in a single center between 01.01.2019 and 01.09.2019 were analyzed. Pregnancy, abortion and live birth outcomes were compared in DCE cycles below and above the threshold value of 10.64 $\mathrm{ng} / \mathrm{ml}$ of progesterone.

Results: According to progesterone concentrations, the age, causes of infertility, stimulation days, body mass index (BMI) values, endometrial thicknesse, and mean number of embryos transferred were similar in the groups. When pregnancy rates were compared in terms of progesterone concentrations, pregnancy rates were significantly higher in the progesterone $>10.65 \mathrm{ng} / \mathrm{ml}$ group $\mathrm{p}=0.023$. We found that $50 \%$ (21) of total pregnancies resulted in a live birth, and $90.5 \%$ (19) of pregnancies resulting in live birth consisted of pregnant women whose progesterone levels were progesterone $>10.64 \mathrm{ng} / \mathrm{ml}$. Those whose progesterone levels were $<10.64 \mathrm{ng} / \mathrm{ml}$ constituted $28.6 \%$ (12) of positive pregnant women, $83.3 \%$ (10) of these pregnancies were found to be with miscarriage, and $16.7 \%$ (2) of them resulted with live births.

Conclusion: It is observed that pregnancy outcomes are higher in cycles where progesterone levels are progesterone $>10.64 \mathrm{ng} / \mathrm{ml}$, and most of the pregnancies that occur result in a live birth.

Keywords: Embryo transfer, hormone replacement therapy, pregnancy outcomes

\author{
Sorumlu Yazar / Corresponding Author: \\ Özcan Budak \\ Sakarya Üniversitesi Tıp Fakültesi Histoloji-Embriyoloji Anabilim \\ Dalı, Sakarya/TÜRKIYE \\ Tel: +90 (546) 8951873 \\ E-mail: ozcanbudak@sakarya.edu.tr
}

Yayın Bilgisi / Article Info:

Gönderi Tarihi/ Received: 15/03/2021

Kabul Tarihi/ Accepted: 10/04/2021

Online Yayın Tarihi/ Published: 05/06/2021

Atıf / Cited: Budak Ö ve ark. Dondurulmuş Çözülmüş Embriyo Transferi Öncesi Günü Progesteron Seviyesinin İn-Vitro Fertilizasyon Başarısına Etkisinin İncelenmesi. Online Türk Sağllk Bilimleri Dergisi 2021;6(2):282-290. doi: 10.26453/otjhs.896726 


\section{GİRIŞ}

Son on yılda DÇET kullanımı dünya çapında yardımla üreme teknikleri (YÜT) tedavi uygulamalarında önemli ölçüde tercih sebebi olmuştur ve giderek yaygınlaşmıştır. DÇET sikluslarında daha önce yapılan taze sikluslarda dondurulan embriyolar çözdürülerek kullanılır. Bu durumun birçok nedeni bulunmaktadır; overyan stimülasyon prtokollerinin gelişmesi, vitrifikasyon işlemlerinde yüksek oranda canlı embriyo elde edilme oranlarının artması, elektif tek embriyo transfer politikasının yaygınlaşması, hiperstümülasyon riski taşıyan kadınlarda all-freeze stratejisinin başarılı bir şekilde uygulanması gibi durumlar sayılabilir. Ayrıca DÇET sonrası implantasyon ve devam eden klinik gebelik oranlar1nın, taze siklus embriyo transferinden (ET) daha iyi olabileceğine ve düşük doğum ağırlıklı bebek oranının, preterm doğumların daha az olduğuna dair yayınlar da mevcuttur. ${ }^{1-3}$ Kriyoprezervasyon sürecindeki gelişim, ${ }^{4}$ preimplantasyonel genetik test (PGT) ihtiyacı olan infertil çiftlerin tedavi sürecine de pozitif katkıda bulunmuştur. ${ }^{5}$ Bununla birlikte, normal ovulasyona sahip hastalarda DÇET öncesi en etkili endometriyum indiksyonu yöntemi üzerinde net bir fikir birliği yoktur. ${ }^{6}$ Nitekim klinik açıdan ET için endometriyal hazırlıkta doğal yolla, çok az hormon eklentisi almış veya tamamıyla hormon eklentisi ile hazırlanan (HRT) endometriyal hazırlıkları sonrasında gebelik ve canlı doğum oranları arasında bir fark görülmemiştir. ${ }^{7,8}$ Endometriyal hazırlıkta HRT son dönemlerde oldukça yaygınlaşmıştır. Bunun sebebi ise HRT'nin implantasyon penceresi süresi içinde transfere olanak sağlamasıdır.

Endometrial reseptivite progesteron hormonunun varlığında etkindir. Klinisyenler tarafından yönetilen hormon eklentili DÇET hazırlığında östrojen ile başlayan transfer hazırlığında implantasyon ve gebelik için final aşamasında progesteronun yeri çok önemlidir. ${ }^{9}$ Endometriyal hazırlık için ardışı östrojen uygulamasına genellikle döngünün başında follikül sitümüle edici hormon (FSH) seviyesinin yükselmesini ve folüküler artışı önlemek için başlanır. Östrojen uygulaması aynı zamanda endometriyal kalınlaşmayı da desteklemektedir. Endometrial kalınlık en az 7 mm'ye ulaştığında, dondurulmuş embriyonun gününe bağlı olarak 2., 3. ve 5. gün olmak üzere progesteron desteği eksojen olarak ET'den önce tedavide kullanılmaya başlanır. Eksojen progesteron ve östrojen desteğinin gebelik sonrası üç ay daha devam edilmesi önerilmektedir. ${ }^{10}$

Lüteal faz desteği için progesteron takviyesinin canlı doğum oranlarını artırdığı düşünülmektedir. ${ }^{10} \mathrm{Bu}$ verilerden dolayı DÇET döngülerinde serum progesteron seviyesinin etkisi yaygın olarak incelenmek istenmiştir. İmplantasyonun gerçekleşmesini ve gebelik kaybını azaltması için belirli bir serum progesteron değerine ulaşılması gerektiği konusunda farklı görüşler vardır. Embriyo transferinde ve gebelik test gününde optimal bir serum progesteron değeri olup olmadığını ve bu serum progesteron değerinin progesteron takviyesi için ideal bir yol olup olmadığını bulmak için birçok girişimde bulunulmuştur. Bu bağlamda, yapılan yakın tarihli bir çalışmada düşük serum progesteron değerinin $(<10,64 \mathrm{ng} / \mathrm{mL})$ euploid embriyoların DÇET transferi sonucunda yüksek düşük ve düşük gebelik oranlarına neden olduğu bildirilmiştir. ${ }^{11}$ Söz konusu çalışma ile öncekiler arasındaki temel fark çalışmadaki serum progesteron düzeylerinin ET gününe ait olmasıdır. ${ }^{12}$ Benzer şekilde, yeni bir çalışma serum progesteron değerinin gebelik testinin yapıldığı gün $<11 \mathrm{ng} / \mathrm{mL}$ olmasının kötü gebelik sonuçlarıyla ilişkili olduğunu ortaya koymuştur. $^{13}$

Progesteron seviyeleri, uterin seviyelerinin serumdaki değerinin 10 kat daha yüksek olduğu bildirildiğinden tedavi rutininde genellikle ölçülmemektedir. ${ }^{14}$ Ancak, yakın zamanda yapılan bir çalışmada serum progesteron konsantrasyonlarının implantasyon döneminde optimal canlı doğum oranları ile ilişkili olduğu bildirilmiştir. ${ }^{15} \mathrm{Bu}$ nedenle, serum progesteron seviyeleri HRT'de kullanıldığında DÇET başarısını etkileyebilmektedir. $\mathrm{Bu}$ bilgiler doğrultusunda mevcut çalışmada, DÇET'den bir gün önce serum progesteron seviyeleri ile gebelik sonucu arasındaki ilişkinin belirlenmesi amaçlamıştır.

\section{MATERYAL VE METOT}

Çalışmamızda Sakarya Üniversitesi Eğitim Araştırma Hastanesi Yardımci Üreme Teknikleri (YÜT) 01.01.2019- ile 01.09.2019 tarihleri arasında DÇET uygulanmış olan hastaların verileri retrospektif olarak incelendi. Çalışmamızın etik izini, Sakarya Üniversitesi Tıp Fakültesi Girişimsel Olmayan Etik Kurulu tarafından onaylanmıştır (Tarih: 27.01.2020, karar no: 32).

Hastalar DÇET öncesi progesteron değerine göre iki gruba ayrıldı. Progesteron eşik değeri olarak 10,64 $\mathrm{ng} / \mathrm{ml}$ kabul edildi ve bu değerlerin üstü ve altındaki progesteron değerlerine göre in vitro fertilizasyon (IVF) sonuçları karşılaştırıldı.

Çalışmaya retrospektif olarak DÇET uygulanmış 67 hastanın siklusları dahil edildi. Hastaların mevcut 
verilerine göre kadın ve erkek yaşları, embriyo transfer günleri, infertilite endikasyonları, endometriyum kalınlığı, hcg-progesteron değerleri, embriyo transferi (ET)-stimülasyon gün sayıları, deneme sayıları, BKİ, klinik gebelik, düşük ve canlı doğum oranları incelendi. Gebelik ET' den 15 gün sonra bakılan gebelik test sonucunun pozitif saptanması durumunda gebeliğin gerçekleştiği kabul edildi. DÇET de kullanılan tüm embriyolar için vitrifikasyon yöntemi kullanıldı.

Endometriyum hazırlığı için; menstrual siklusun 21 . günü 10 IU Lucrin başlandı ve adet görünceye kadar uygulama devam edildi. Menstrual siklus başlayınca doz 5 IU' ye düşürüldü ve ertesi gün Progesterona başlanıld1. Menstruasyonun 1. günü oral estrofem 2mg 3x1 başland 1 ve insan koryonik gonadotropin beta $(\beta-H C G)$ hormon düzeyi bakılan güne kadar devam edildi. Siklusun 4. gününde östradiol $\left(E_{2}\right)$ düzeyi $180 \mathrm{pg} / \mathrm{mL}$ altında ise eksojen $\mathrm{E}_{2}$ dozu 8 mg'a çıkarıldı. 14-16. günlerde endometrium kalınlığ $8 \mathrm{~mm}$ ve üzerinde olanlara vajinal $400 \mathrm{mg}$ progestan başlandi. $\mathrm{E}_{2}$ ve progesteron takviyesi gebelik elde edilenlerde 10. haftaya kadar devam edildi. Progesteron takviyesi çözdürülüp transfer edilen embriyonun gününe göre devam edildi.

İstatistiksel Analizler: İstatistiksel analizler SPSS 24.0 paket programı (SPSS Inc. ve Lead Tech. Inc. Chicago. ABD) kullanılarak yapıldı. Verilerin normal dağılıma uygunluğunda Kolmogrov-Smirnov testi kullanıldı. Normal dağılım gösteren numerik verilerde Student t-testi, normal dağılmayan numerik verilerde Mann Whitney U testi kullanıldı. Kategorik veriler değerlendirilirken yerine göre ki-kare ya da Fisher Exact test ile yapıldı. Sonuçlar ortalama \pm standart sapma (SD) ve yüzde olarak verildi. $\mathrm{P}<0,05$ olduğunda istatistiki olarak anlamlı kabul edildi.

\section{BULGULAR}

Çalışmaya DÇET yapılan 67 çift alındı ve progesteron eşiğine göre progesteron $<10,64 \mathrm{ng} / \mathrm{ml}$ $(\mathrm{n}=27)$ ve progesteron $>10,64 \mathrm{ng} / \mathrm{ml}(\mathrm{n}=40)$ şeklinde 2 gruba ayrıldı. Çalışmaya alınan kadınların yaş ortalaması $30,3 \pm 4,11$ yıl erkeklerin yaş ortalaması ise $33,7 \pm 4,41$ yıl olduğu bulundu. Kadınların ortalama BKİ 24,22 \pm 3 ,88 olarak bulundu. Hastalara ait demografik özellikler Tablo 1'de verildi.

Progesteron eşiği dikkate alınarak yapılan istatistiksel karşılaştırmada progesteron $>10,64 \mathrm{ng} / \mathrm{ml}$ olanlarda ortalama hcg-progesteron düzeyleri $21,02 \pm 7,96$ $\mathrm{ng} / \mathrm{ml}$ düzeyinde, progesteron $<10,64 \mathrm{ng} / \mathrm{ml}$ olanlarda ortalama 7,943 $\pm 3,462$ düzeyinde olduğu bulundu. $\mathrm{Bu}$ farklılığın istatistiksel açıdan yüksek düzeyde anlamlı olduğu belirlendi $(\mathrm{p}=0,000)$. Ortalama endometrium kalınlığı progesteron $>10,64 \mathrm{ng} / \mathrm{ml}$ grubunda daha yüksek olmasına rağmen gruplar arasında anlamlı bir farklılık yoktu $(\mathrm{p}>0,05)(\underline{\text { Tablo }}$ 1). Hastalar infertilite etyolojisi açısından değerlendirildiğinde erkeklerde endikasyon nedeni \%53,7 oranında erkek faktörü iken, kadınlarda başlıca endikasyon nedeninin \%47,8 oranında açıklanamayan infertilite olduğu bulundu (Tablo 2).

Çalışmaya katılan ve IVF uygulaması sonrasında gebelik sonuçları açısından yapılan değerlendirmede önemli farklılıklar olduğu görüldü (Grafik 1, Tablo 3). Toplam 67 hastadan 42'sinde gebeliğin gerçekleşmiş olduğu, gebelerin $\% 71,4 \quad$ (30)'ünün progesteron düzeylerinin $>10,64 \mathrm{ng} / \mathrm{ml}$ üzerinde olduğu ve istatistiksel açıdan da anlamlı olduğu bulundu ( $\mathrm{p}=0,002)$.

Sonuçlanan gebeliklerin \%90,5 (19)'nin progesteron düzeylerinin $>10,64 \mathrm{ng} / \mathrm{ml}$ olan gebelerden oluştuğu bulundu. Progesteron düzeyleri $<10,64 \mathrm{ng} / \mathrm{ml}$ olanların pozitif gebelerin \%28,6 (12)'sını oluşturduğu, bu gebeliklerin \%83,3 (10)'ünün düşük, \%16,7 (2)'sinin de canlı doğum ile sonuçlandığı bulundu.

Tüm bu sonuçlar progesteron düzeylerinin $>10,64$ $\mathrm{ng} / \mathrm{ml}$ olması durumunda gebelik gerçekleşme ihtimalinin daha yüksek olduğunu ve oluşan gebeliklerin büyük çoğunluğunun canlı doğumla sonuçlandığını göstermektedir.

\section{TARTIŞMA VE SONUÇ}

Çalışmamız, DÇET'den bir gün önce ölçülen progesteron seviyelerinin, ET'i takiben tedavi başarısının güçlü bir belirleyicisi olduğunu göstermektedir. ET'den önceki gün serum progesteron $<10,64$ $\mathrm{ng} / \mathrm{ml}$ olan hastalarda, transfer sonrasında önemli ölçüde daha yüksek düşük oranına ve düşük canlı doğum oranına sahip olduğu belirlendi.

Çalışmamıza benzer olarak, ET gününde progesteron seviyelerini ölçen daha önce yapılan bir çalışma ile aynı doğrultudadır. ${ }^{12} \mathrm{Bu}$ sonuçlar ET gününde (veya önceki gün) düşük progesteron seviyesinin daha kötü IVF başarısına neden olabileceği fikrini desteklemektedir. Bizim çalışmamızla ufak bir fark olarak yapılan çalışmada progesteron ölçüm günü ET gününde olmasıdır. Biz çalışmamızda progesteron ölçümünü transfer öncesi gün gerçekleştirmiştik. DÇET'de serum progesteronun etkisi daha önce çalışılmış olup, lüteal faz progesteron takviyesinin canlı doğum oranlarını attırdığı vurgulanırken düşük oranıyla ilgili verilerde tam bir fikir birliği oluşmamıştır. ${ }^{16,17}$ ET günü için optimal serum progesteron değerleri konsantrasyonlarının aralığını 
bulmak için yapılan girişimler çelişskili sonuçlar vermiştir. $^{15,18}$

Yapılan başka bir çalışmada, ET sonrası intramüsküler ve oral uygulamaya kıyasla daha iyi serum progesteron seviyesi ve DÇET sikluslarında daha yüksek implantasyon oranları nedeniyle progesteron takviyesi için vajinal yol seçilmiştir. ${ }^{19}$ Vajinal progesteron uygulamasından sonra serumda ve endometriumda intramüsküler yola kıyasla daha yüksek serum progesteron seviyeleri ölçülmesini rağmen, endometriumda histolojik, ultrasonografik ve immünositokimyasal reseptör analizlerinde hiçbir farklılık olmadığı gösterilmiştir. ${ }^{20}$ Son olarak, vajinal progesteron desteğinin hastalar için daha uygun olduğu kanıtlanmıştır. ${ }^{21}$

Daha yüksek, düşük oranları ile ilişkili olarak düşük serum progesteron değerlerinin önemini yorumlamak zordur. ${ }^{22}$ Gebelik kaybını azaltmak için yeterli immünolojik ortam sağlamak ve belirli bir serum progesteron değerlerine ulaşılması gerektiği, ancak düşük serum progesteron seviyelerinde de implantasyonun gerçekleşebileceği göz ardı edilmemelidir. Doğal döngüde progesteron, luteal fazda salgılanır. $\mathrm{Bu}$ aşamada progesteron etkisi ile endometriyal epitel proliferasyon stromal farklılaşma, lokal immün yanıt ve anjiyogenez, tamamen embriyoya implantasyon izin verir. $^{23}$ Düşük progesteron seviyelerinde ise endometriyal farklılaşmanın yeterli derecede gerçekleşmediği düşünülebilir. Oligoamenoresi olan hastalarda DÇET siklusları sırasında iki katına çıkarılan jel takviyesinin erken dönemlerde gebelik kaybı oranını düşürdüğü gösterilmiştir. Bu çalışmada serum progesteron seviyelerinin daha sonra analiz edilmediği bildirilmiştir. ${ }^{24}$

Tüm bu bulguların klinik sonuçlara şöyle bir katkısı bulunabilir. Progesteronun düşük serum konsantrasyonuna rağmen, vajinal progesteron ile endometriyal gelişimin desteklenmesi durumunda başarılı gebelikler ve canlı doğum oranları elde edilebilir. ${ }^{25} \mathrm{Bu}$ veriler tedavi sürecinde farklı yaklaşımlara olanak sağlayabilir. Progesteron desteği sağlanabileceği sikluslar olabileceği gibi, progesteron değerlerinin düşük olduğu vakalarda ise siklus iptali tercihine imkan sağlayabilir. Böylelikle, bir sonraki DÇET için endometriyal hazırlığın daha uygun yapılabilmesine olanak sağlayarak implantasyon ve klinik gebelik ihtimali artırılmış olabilir.

Çalışma sonuçlarımızdan açıkça görülmektedir ki yüksek progesteron değerleri yüksek gebelik ve can11 doğum oranlarını artırmaktadır. Düşük progesteron değerlerine sahip DÇET sikluslarında ise yeterli gebelik oranlarını elde etmek için eksojen progesteron takviyesi yapılarak serum progesteron seviyesinin arttırılmasının faydalı olabileceğini düşünmekteyiz. Progesteron değerleri ile ilgili hasta sayısının arttırıldığı yeni çalışmalar yapılarak bulgularımızın desteklenmesi gerekmektedir.

Etik Komite Onayı: Bu çalışma Sakarya Üniversitesi Tıp Fakültesi Girişimsel Olmayan Etik Kurulu tarafından onaylanmıştır (Tarih: 27/01/2020, karar no:32).

Çıkar Çatışması: Yazarlar çıkar çatışması bildirmemektedir.

Yazar Katkıları: Fikir ÖB, NA, VT; Denetleme ÖB, MSB; Malzemeler - ÖB, SÖ, SD; Veri toplanması ve işlemesi - ÖB, SÖ, ASC; Analiz ve yorum ÖB, SÖ, SD; Yazıyı yazan -ÖB, MSB, SD, SÖ.

Hakem değerlendirmesi: Dış bağımsız.

\section{KAYNAKLAR}

1. Bhattacharya S. Maternal and perinatal outcomes after fresh versus frozen embryo transfer-what is the risk-benefit ratio? Fertility and Sterility. 2016;106(2):241-243.

2. Maheshwari A, Pandey S, Shetty A, Hamilton M, Bhattacharya S. Obstetric and perinatal outcomes in singleton pregnancies resulting from the transfer of frozen thawed versus fresh embryos generated through in vitro fertilization treatment: a systematic review and meta-analysis. Fertility and Sterility. 2012;98(2):368-377.

3. Wennerholm UB, Henningsen AK, Romundstad LB, Bergh C, Pinborg A, Skjaerven R, et al. Perinatal outcomes of children born after frozenthawed embryo transfer: a Nordic cohort study from the CoNARTaS group. Human Reproduction (Oxford, England). 2013;28(9):2545-2553.

4. Rienzi L, Gracia C, Maggiulli R, et al. Oocyte, embryo and blastocyst cryopreservation in ART: systematic review and meta-analysis comparing slow-freezing versus vitrification to produce evidence for the development of global guidance. Human Reproduction Update. 2017;23(2):139155.

5. Coates A, Kung A, Mounts E, et al. Optimal euploid embryo transfer strategy, fresh versus frozen, after preimplantation genetic screening with next generation sequencing: a randomized controlled trial. Fertility and Sterility. 2017;107 (3):723-730.

6. Mackens S, Santos-Ribeiro S, van de Vijver A, et al. Frozen embryo transfer: a review on the opti- 
mal endometrial preparation and timing. Human Reproduction. 2017;32(11):2234-2242.

7. Groenewoud ER, Cohlen BJ, Macklon NS. Programming the endometrium for deferred transfer of cryopreserved embryos: hormone replacement versus modified natural cycles. Fertility and Sterility. 2018;109(5):768-774.

8. Yarali H, Polat M, Mumusoglu S, Yarali I, Bozdag G. Preparation of endometrium for frozen embryo replacement cycles: a systematic review and meta-analysis. Journal of Assisted Reproduction and Genetics. 2016;33(10):1287-1304.

9. Gellersen B, Brosens JJ. Cyclic decidualization of the human endometrium in reproductive health and failure. Endocrine Reviews. 2014;35(6):851905.

10. Paulson RJ. Hormonal induction of endometrial receptivity. Fertility and Sterility. 2011;96(3):530 -535 .

11. Gaggiotti-Marre S, Martinez F, Coll L, et al. Low serum progesterone the day prior to frozen embryo transfer of euploid embryos is associated with significant reduction in live birth rates. Gynecological endocrinology : the official journal of the International Society of Gynecological Endocrinology. 2019;35(5):439-442.

12. Labarta E, Mariani G, Holtmann N, Celada P, Remohí J, Bosch E. Low serum progesterone on the day of embryo transfer is associated with a diminished ongoing pregnancy rate in oocyte donation cycles after artificial endometrial preparation: a prospective study. Human Reproduction. 2017;32(12):2437-2442.

13. Alsbjerg B, Thomsen L, Elbaek HO, et al. Progesterone levels on pregnancy test day after hormone replacement therapy-cryopreserved embryo transfer cycles and related reproductive outcomes. Reproductive Biomedicine Online. 2018;37(5):641-647.

14. De Ziegler D, Bulletti C, De Monstier B, Jääskeläinen AS. The first uterine pass effect. Annals of the New York Academy of Sciences. 1997;828:291-299.

15. Yovich JL, Conceicao JL, Stanger JD, Hinchliffe PM, Keane KN. Mid-luteal serum progesterone concentrations govern implantation rates for cryopreserved embryo transfers conducted under hormone replacement. Reproductive Biomedicine Online. 2015;31(2):180-191.

16. Bjuresten K, Landgren BM, Hovatta O, StavreusEvers A. Luteal phase progesterone increases live birth rate after frozen embryo transfer. Fertility and Sterility. 2011;95(2):534-537.

17. Kim CH, Lee YJ, Lee KH, et al. The effect of luteal phase progesterone supplementation on natural frozen-thawed embryo transfer cycles. Obstetrics \& Gynecology Science. 2014;57 (4):291-296.

18. Brady PC, Kaser DJ, Ginsburg ES, et al. Serum progesterone concentration on day of embryo transfer in donor oocyte cycles. Journal of Assisted Reproduction and Genetics. 2014;31 (5):569-575.

19. Buvat J, Marcolin G, Guittard C, Herbaut JC, Louvet AL, Dehaene JL. Luteal support after luteinizing hormone-releasing hormone agonist for in vitro fertilization: superiority of human chorionic gonadotropin over oral progesterone. Fertility and Sterility. 1990;53(3):490-494.

20. Miles RA, Paulson RJ, Lobo RA, Press MF, Dahmoush L, Sauer MV. Pharmacokinetics and endometrial tissue levels of progesterone after administration by intramuscular and vaginal routes: a comparative study. Fertility and Sterility. 1994;62(3):485-490.

21. Khan N, Richter KS, Newsome TL, Blake EJ, Yankov VI. Matched-samples comparison of intramuscular versus vaginal progesterone for luteal phase support after in vitro fertilization and embryo transfer. Fertility and Sterility. 2009;91 (6):2445-2450.

22. La Rocca C, Carbone F, Longobardi S, Matarese G. The immunology of pregnancy: regulatory $\mathrm{T}$ cells control maternal immune tolerance toward the fetus. Immunology Letters. 2014;162(1 Pt A):41-48.

23. Bhurke AS, Bagchi IC, Bagchi MK. Progesterone-Regulated endometrial factors controlling implantation. American Journal of Reproductive Immunology. 2016;75(3):237-425.

24. Alsbjerg B, Polyzos NP, Elbaek HO, Povlsen $\mathrm{BB}$, Andersen CY, Humaidan P. Increasing vaginal progesterone gel supplementation after frozen -thawed embryo transfer significantly increases the delivery rate. Reproductive Biomedicine Online. 2013;26(2):133-137.

25. Salat-Baroux J, Cornet D, Alvarez S, et al. Pregnancies after replacement of frozen-thawed embryos in a donation program. Fertility and Sterility. 1988;49(5):817-821. 
Tablo 1. Çalışmaya alınan çiftlerin demografik özellikleri.

\begin{tabular}{|c|c|c|c|}
\hline Parametre & $\begin{array}{c}\text { Progesteron }<10,64 \mathrm{ng} / \\
\mathrm{ml}(\mathrm{n}=\mathbf{2 7})\end{array}$ & $\begin{array}{c}\begin{array}{c}\text { Progesteron }>10,64 \mathrm{ng} / \\
\mathrm{ml} \\
(\mathrm{n}=40)\end{array} \\
\text { Ortalama } \pm \text { SD }\end{array}$ & P değeri \\
\hline Kadın yaş & $29,703 \pm 3,450$ & $30,750 \pm 4,499$ & 0,311 \\
\hline Erkek yaş & $33,000 \pm 3,951$ & $34,325 \pm 4,670$ & 0,231 \\
\hline BKİ & $24,143 \pm 3,887$ & $24,276 \pm 3,932$ & 0,892 \\
\hline Endometrium kalınlığı (mm) & $9,016 \pm 2,131$ & $9,439 \pm 1,546$ & 0,873 \\
\hline Hcg-Progesteron & $7,943 \pm 3,462$ & $21,026 \pm 7,964$ & $0,000 *$ \\
\hline Et+Stim gün sayısı & $20,889 \pm 3,423$ & $20,900 \pm 2,436$ & 0,527 \\
\hline Et günü & $4,185 \pm 1,001$ & $4,200 \pm 0,992$ & 0,952 \\
\hline Deneme Sayısı & $2,370 \pm 0,966$ & $2,225 \pm 0,767$ & 0,532 \\
\hline
\end{tabular}

SD: Standart sapma; n: Sayı; BKİ: Beden Kitle İndeksi; Hcg-progesteron: Hcg günü progesteron ng/ml; Et: Embriyo transferi; Et+Stim. gün-sayısı: Embriyo transferi+Stimülasyon gün sayısı; ET: Embriyo transferi; *: p $<0,05$ anlamlı olarak kabul edildi. 
Tablo 2. Çalışmaya dahil edilen hastaların infertilite etyolojisi.

\begin{tabular}{|c|c|c|c|}
\hline İnfertilite Etyolojisi & $\begin{array}{c}\text { Progesteron } \\
<\mathbf{1 0 , 6 4} \mathrm{ng} / \mathrm{ml}(\mathrm{n}=\mathbf{2 7})\end{array}$ & $\begin{array}{c}\text { Progesteron } \\
>10,64 \mathrm{ng} / \mathrm{ml}(\mathrm{n}=40)\end{array}$ & Toplam \\
\hline Endikasyon kadın & n (\%) & n (\%) & n (\%) \\
\hline Anovulasyon & $1(3,7)$ & $6(15)$ & $7(10,4)$ \\
\hline Açıklanamayan-infertilite & $13(48,1)$ & $19(47,5)$ & $32(47,8)$ \\
\hline Endometriozis & $4(3,2)$ & $4(10)$ & $8(11,9)$ \\
\hline Tubal faktör & $2(7,4)$ & $2(5)$ & $4(6)$ \\
\hline PCOS & $7(25,9)$ & $9(22,5)$ & $16(23,9)$ \\
\hline Endikasyon Erkek & n (\%) & n (\%) & n (\%) \\
\hline Erkek faktörü & $16(59,3)$ & $20(50)$ & $36(53,7)$ \\
\hline Açıklanamayan infertilite & $11(40,7)$ & $20(50)$ & $31(46,3)$ \\
\hline
\end{tabular}

PCOS: Polikistik over sendromu; n: Sayı. 


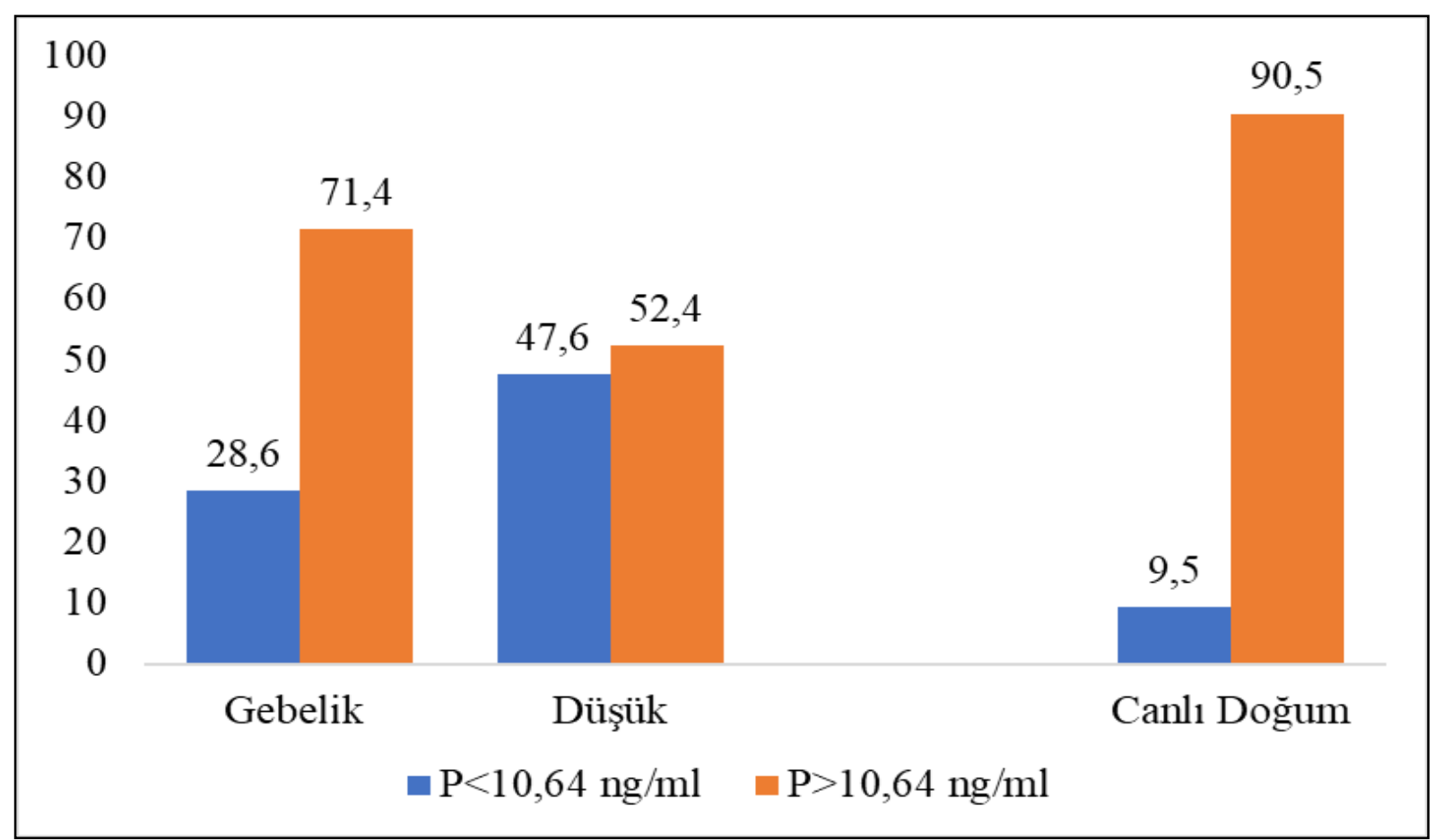

Grafik 1: Tüm hastalarda Progesteron (P) düzeylerine göre gebelik, düşük ve canlı doğum gerçekleşme yüzdeleri. 
Tablo 3. Tüm hastalarda progesteron düzeylerine göre gebelik, düşük ve canlı doğum gerçekleşme yüzdeleri.

\begin{tabular}{|l|c|c|c|}
\hline Parametre & $\begin{array}{c}\text { P<10,64 ng/ml } \\
\text { n (\%) }\end{array}$ & $\begin{array}{c}\text { P>10,64 ng/ml } \\
\text { n (\%) }\end{array}$ & $\begin{array}{c}\text { Toplam } \\
\text { n (\%) }\end{array}$ \\
\hline Gebelik Pozitif & $12(28,6)$ & $30(71,4)$ & $42(100)$ \\
\hline Düşük & $10(47,6)$ & $11(52,4)$ & $21(100)$ \\
\hline Canlı Doğum & $2(9,5)$ & $19(90,5)$ & $21(100)$ \\
\hline
\end{tabular}

P: Progesteron; n: Sayı. 